\title{
Can CEOs' Facial Attractiveness Influence Philanthropic Behavior? Evidence from India
}

\begin{abstract}
This study extends the extant literature on corporate philanthropy by exploring the indirect effect of physical attractiveness of CEOs on corporate philanthropy under conditional effects of family ownership and control. Recent empirical studies in psychology suggest that egalitarian values are negatively related to physical attractiveness. Based on these findings, we propose that physically attractive CEOs invest less in corporate philanthropic activities than less attractive peers as they have lower egalitarian values. Leveraging upper echelons and stewardship theory, we further consider the moderating impact of family ownership and control on the indirect relationship between the physical attractiveness of a CEO and philanthropy mediated through egalitarianism.
\end{abstract}

\section{Keywords}

corporate philanthropy, physical attractiveness, egalitarian value, family ownership and family control 
To what extent do chief executive officers (CEOs) impose their personal values on philanthropy decisions? This question is of substantial practical significance, especially for corporate boards and society at large. Upper echelon theory asserts that strategic decision-making in general is less of a technical endeavor than an interpretive one, and executives interpret business situations through highly personalized lenses, shaped by their experiences, personalities, and values. Among the many empirical tests of upper echelons theory, the vast majority have examined the effects of CEOs' demographic traits (Huang, 2013; Manner, 2010); a few have explored the effects of CEOs' personalities (Petrenko, Aime, Ridge, \& Hill, 2016); and fewer have considered the role of CEOs' values in corporate philanthropy (Buchholtz, Amason, \& Rutherford, 1999).

However, demographic traits were criticized for the black box problem (Hambrick, 2007). Furthermore, scant attention was given to more underlying traits of executives such as their values as they were not directly observable or measurable (Brickley, Smith, \& Zimmerman, 1997, p. 27). Although psychologists might argue that psychometric measures for gauging managerial values could be formulated, Hambrick, commenting on the limitations of psychometric measures, stated: "It requires very intrusive access to large numbers of executives...who are notoriously unwilling to submit themselves to scholarly poking and probing" (Hambrick, 2007, p. 337).

Recent empirical developments in the field of psychology have found a relationship between physical traits of individuals, such as physical attractiveness, and their underlying egalitarian values, thus also resolving the black box problem by associating demographic traits of individuals (like physical appearance) with underlying values. For instance, Price, Kang, Dunn, and Hopkins (2011) found that physically attractive individuals had lower egalitarian values. Business ethics scholars on the other hand found that CSR activities of a firm, such as philanthropy, are influenced by a manager's egalitarian values. For instance, Panwar, Paul, Nybakk, Hansen, \& 
Thompson (2014) suggested that individuals with egalitarian beliefs supporting rectification of existing inequalities in society and philanthropy were a vital instrument for eliminating these inequalities (Bobo, 1991; Feldman \& Steenbergen, 2001).

The above-mentioned findings in the field of psychology and corporate philanthropy have significant implications for predicting philanthropic decisions taken by CEOs. As the physical attractiveness of CEOs can help scholars predict their egalitarian values and hence interest in philanthropy, our study provides an opportunity to respond to repeated calls by Hambrick to incorporate managerial values in corporate philanthropic decisions (Hambrick \& Mason, 1984; Hambrick, 2007), while at the same time resolving the black box problem to some extent by theoretically connecting physical attractiveness as a demographic trait (Morrow, 1990) to the moral and personal values of a CEO, which is significantly important for philanthropic decisions (Hemingway \& Maclagan, 2004).

Conducting such a study, especially in the Indian context has even greater significance. In 2018, the Ministry of Corporate Affairs in India issued preliminary notices to nearly 300 firms for not complying with philanthropic spending requirements as set by the government ("Centre issues notice,” 2018). Furthermore, despite India being one of the fastest growing emerging market, it remains least philanthropic country amongst all South Asian nations (Manku, 2015). Even Jason Wingard, vice-dean of executive education at the Wharton School, indicated that it was ironic that “even as the country's [India's] recent economic boom has created a new class of millionairesmuch as the Industrial Revolution did in America at the end of the 19th century - these individuals and successful Indian corporations have been slow to increase their levels of charitable giving" ("How India's new philanthropists," 2011). India's richest one percent held 58 percent of the country's total wealth, while the global richest one percent held 50 percent of wealth ("Income 
inequality gets worse," 2019). Thus, the poor-rich divide was comparatively higher in India, making philanthropic donations even more relevant for India. Finally, scholars have also urged to explore in detail the drivers of corporate philanthropy in emerging markets such as India (Jamali \& Karm, 2018). Thus, by conducting a country specific study, our study contributes towards the understanding of variation in philanthropy among firms as influenced by CEOs physical attractiveness.

Nevertheless, CEOs do not have complete discretion in injecting personal values into strategic decisions, including corporate philanthropy. They are limited by the influence of other top management team (TMT) executives as well as the ownership concentration and control of family members. In emerging markets such as India, since business are usually owned by families (Khanna \& Palepu, 2000) and they are likely to have an influence on decisions made by the CEOs depending on their level of ownership and control (Peng \& Jiang, 2010), we test the relationship between a CEO's physical attractiveness and corporate philanthropy within the boundary condition set by the family business, i.e., their ownership and control. Based on stewardship theory (Anderson \& Reeb, 2003; Davis, Schoorman, \& Donaldson, 1997) we assert that family members of a firm are likely to consider themselves as stewards and give importance to non-economic goals as well (Lamb \& Butler, 2018). As ownership concentration and control of family members increases, egalitarian values of physically attractive CEOs may not be able to negatively impact philanthropy as much compared to when ownership concentration is low or CEO is not a family member. Based on a sample of 647 firms and subsequently 162 family firms, we find evidence in support of our propositions. 


\section{Literature Review and hypothesis}

\section{Corporate Philanthropy and Egalitarian Values}

Though the significance of organization-level factors in promoting philanthropy is indisputable, however, the role of CEO traits on philanthropic decisions cannot be ignored, as it is the CEOs who make most of the corporate decisions. In this context, the role of CEO personality (Petrenko et al., 2016), attitude (Dennis, Buchholtz, \& Butts, 2009) and values (Choi \& Wang, 2007) on corporate philanthropy has been explored. Extending the literature, we specifically explore how egalitarian values of $\mathrm{CEO}$ as signaled through their physical attractiveness (Price, Brown, Dukes, \& Kang, 2015; Price et al., 2011) could influence their corporate giving behavior. We explain our assertions ahead.

Egalitarianism refers to an individual's belief in the equitable distribution of resources (Nathan, 1983). An individual is considered egalitarian when he or she believes that social status and other resources should be equally held across all social groups. Thus, such individuals are more likely to believe in charity and philanthropy so that the suffering segment of the society such as poor citizens could also benefit. However, not all individuals are egalitarian. Recent studies indicate that physically attractive individuals are less likely to have egalitarian values (Price et al., 2015; 2011).

\section{Physical Attractiveness and Egalitarian Values}

Studies in the field of psychology have empirically found that the physical attractiveness of an individual was negatively related to egalitarianism, especially in males (Price et al., 2011, 2015). Holtzman, Augustine, and Senne (2011) have confirmed facial attractiveness was negatively related to prosocial behavior, a trait related to egalitarianism (Zhao, Ferguson, \& Smillie, 2016). The study by Holtzman et al. (2011) specifically found that prosocial traits such as 
empathy were negatively associated with facial symmetry, where facial symmetry is considered to be a measure of facial attractiveness (Grammer and Thornhill, 1994). In fact, Grammer and Thornhill in their research claimed their study was the "first study to indicate that measured facial symmetry affects positive judgments about facial attractiveness" (p. 240). For this reason, software like Anaface (that we employ in this study) also measures facial attractiveness based on facial symmetry (Hooton, 2014). Other studies focusing on bodily attractiveness also reached a similar conclusion. In a prisoner's dilemma game in many experimental economic studies, individuals who were more attractive did not cooperate with others (Sanchez-Pages \& Turiegano, 2010; Shinada \& Yamagishi, 2014; Takahashi, Yamagishi, Tanida, Kiyonari, \& Kanazawa, 2006; Zaatari \& Trivers, 2007). Similarly, it was found that attractive males were inegalitarian in resource distribution decisions. In a study focused on evaluating redistribution of wealth (from richer to poorer) by rich males, it was found that attractive males were more likely to oppose this redistribution (Petersen, Sznycer, Sell, Cosmides, \& Tooby, 2013).

Scholars have explained several possible reasons for this negative relationship between egalitarianism and physical attractiveness. Physically attractive people are preferable social associates (Langlois et al., 2000). This is because attractiveness creates a "halo effect," where attractiveness is assumed to be linked with several other underlying positive traits, such as intelligence, social skills, health, and developmental stability (Dion, 2002; Eagly, Ashmore, Makhijani, \& Longo, 1991; Feingold, 1992; Grammer, Fink, Møller, \& Thornhill 2003; Nedelec \& Beaver, 2014). The halo effect results in the preferential treatment of physically attractive people. For instance, political electoral candidates were found to have an advantage if they looked more attractive (Banducci, Karp, Thrasher, \& Rallings, 2008; Ballew \& Todorov, 2007; King \& Leigh, 2009). Similar implications were found for preferential job offers or higher wages given to 
attractive individuals (Paik et al., 2014; Hamermesh \& Biddle, 1994), along with other forms of preferential treatment in society (Eagly et al., 1991; Haidt \& Keltner, 2004). The preferential treatment given to attractive individuals increases their bargaining power in social settings by increasing their persuasive abilities. For instance, attractiveness of a presenter may prompt conscious cognitive or subconscious response inferences about the person's expertise, capabilities and trustworthiness, thus enhancing their power on the receiver (Praxmarer \& Rossiter, 2009).

This enhanced bargaining power of physically attractive people has implications for egalitarian values. Explaining egalitarian implications for attractive people, Price, SheehySkeffington, Sidnaius, and Pound (2017) stated:

"Due to their increased bargaining power, formidable/attractive individuals would have been relatively more likely to prevail in social competitions, and thus to benefit from the inequities in status and resource distribution that would have been the outcome of such competitions (p.626)."

Price et al. (2017) further explained that this ability of physically attractive individuals "to benefit from social norms that promote inequality" rather than norms that encourage equality resulted in a reduced tendency to support egalitarian norms (Price et al., 2015, Price et al., 2011). Extending these findings to the field of business management, the physical attractiveness of CEOs has significant implications for their egalitarian values and thus philanthropic behavior as explained ahead. Hence, we hypothesize:

Hypothesis 1a: Egalitarian values of a CEO are positively associated with corporate philanthropic activities of an organization.

\section{Physical Attractiveness and Philanthropy-Mediating Effect of Egalitarian Belief}

Empirical findings in field of psychology indicate that physically attractive CEOs are likely to have lower egalitarian values. The egalitarian doctrine rests on the idea that all human beings are 
equal in fundamental worth or moral status. Egalitarian individuals believe in equality of some sort, such as that people deserve to receive the same resources or be treated the same (Arneson, 2002). Egalitarian values, thus, imply believing in one's obligation to meet the basic needs of individuals in society and redress the problem of social inequality (Bobo, 1991). Those with egalitarian values have positive attitudes towards social welfare policies and work to uplift the socio-economic status of people in need. Individuals with egalitarian beliefs also have a higher social responsibility orientation and positive attitude towards different aspects of CSR, such as philanthropy or having prosocial values (De Cremer \& Van Lange, 2001; Thompson, Panwar, \& Hansen, 2010). For instance, CEOs with higher egalitarian values were found to have less vertical pay inequity (Chin \& Semadeni, 2017), to be more even-handed in allocating firm resources (Gupta, Briscoe, \& Hambrick,2018), and to invest more in CSR activities (Chin, Hambrick, \& Treviño, 2013), compared to less egalitarian peers.

Overall, CEOs who are physically attractive are less likely to hold egalitarian values and thus may not prefer investment in philanthropic activities. Hence, we hypothesize:

Hypothesis 1b: Corporate philanthropic activities of an organization are negatively associated with the physical attractiveness of a CEO.

Hypothesis 1c: Egalitarian value mediates the relationship between corporate philanthropy and physical attractiveness of a CEO.

\section{Family Firms and Stewardship Theory}

The notion of stewardship is synonymous with family businesses (Donaldson \& Davis, 1991). Being a "steward" implies being a "baton-holder," as family business owners must ensure multigenerational sustainability of business (Campopiano, De Massis, \& Chirico, 2014). This sustainability of business is likely to be accomplished by not only taking care of family members 
but also developing and maintaining trustworthy relationship with outside stakeholders, such as the community at large (Fox \& Hamilton, 1994; Le Breton-Miller \& Miller, 2006; Miller \& Le Breton-Miller, 2005). Philanthropy provides an appropriate platform to support the community at large, as it helps bolster reputation and social capital among external stakeholders (Campopiano et al., 2014), thereby ensuring long-term sustenance of the business ( $\mathrm{Li}, \mathrm{Au}, \mathrm{He}, \&$ Song, 2015). Although social expectations to engage in philanthropic activities exist for all types of business, the notion of stewardship makes these expectations even more vital for family firms. Empirical evidence also suggests that family firms believe that philanthropic activities would grant them the reputational capital necessary for long-term business survival (Breeze, 2009). For instance, in the United States, philanthropic donations by family firms and foundations have been of the order of $\$ 67$ billion per year, representing 2.8 percent of total income (Feliu \& Botero, 2016). In Indian family business also, philanthropic donations have been of the order of 3.10 percent of the total income of firms_(“The million dollar donors report," 2015), almost equivalent to those of American family firms.

However, the extent to which family firms follow stewardship behavior depends on the ownership concentration of members of family firms in the business_(Westhead \& Howorth, 2006). As the ownership concentration of family members increases, their commitment towards sustainable goals of the business also increases_(Soleimanof, Rutherford, \& Webb, 2018). Thus, family firms with a high ownership concentration have a greater propensity to ensure the longterm viability of the business, nurture a personal relationship with external stakeholders, including society, and enhance the reputation of the business through philanthropic activities (Campopiano et al., 2014). Conversely, when family ownership concentration is low, family members are less concerned about passing the "baton" to future generations, so attaining external stakeholder 
support becomes less relevant for them. This is likely to be even more true for family firms in India. Since institutional mechanisms in these markets are weak, family firms often rely on trustworthy relationships to conduct their business (Lamin, 2013). Thus, Indian family firms need to be even more proactive in their philanthropic activities to gain the support of the community at large (Lev, Petrovits, \& Radhakrishnan, 2010) to ensure long term sustenance of the business (Habbershon \& Williams, 1999).

Furthermore, as ownership concentration of family members increases, their ability and intent to effectively monitor the actions of the CEO also increases (Chen, Cheng, \& Dai, 2013). Thus, they are more likely to be involved in decisions taken by CEOs and influence corporate practices such as philanthropy. This implies that as ownership concentration of family members increases, the impact of CEOs' personal values like egalitarianism on corporate decisions like philanthropy may decline (Chin, Hambrick, \& Treviño, 2013). This is because, high family ownership concentration implies high power the family is able to exercise over CEO, less impact that CEOs' egalitarian values could have in presence of heightened stewardship value of family menbers and this less discretion that CEO could exercise in making philanthropic decisions (Arregle, Hitt, Sirmon, and Very, 2007).

Thus, higher levels of ownership concentration by family members would mitigate the effect of the egalitarian values disposition of the CEO on corporate philanthropy. Conversely, lower levels of ownership by family members will increase the discretion exercising ability of the CEO and the CEO's egalitarian values will be more highly reflected in the corporate philanthropy. In other words, the ability of a physically attractive CEO, driven by low egalitarian values, is likely to be inhibited by the stewardship values established by family members of the business. With an increase in ownership concentration of family members, a CEO is more likely to mend his behavior 
towards philanthropy owing to the informal power bestowed in the hands of family members (Arrègle, Hitt, Sirmon, \& Very, 2007). Overall, despite having personal likeability to promote inequality through diminished egalitarian values, even a physically attractive CEO would increase philanthropic activities when ownership concentration is high. Hence, we hypothesize:

Hypothesis 2. CEO facial attractiveness has a conditional indirect effect on corporate philanthropy through egalitarian values, where the mediation effect of egalitarian values is moderated by family ownership, such that the indirect effect of CEO physical attractiveness on corporate philanthropy is more negative when family ownership concentration is low.

\section{Outsider vs. Family CEO}

In many family firms, members of the family are also involved in the management of the firm by holding executive positions in the business, thus being a part of the management beyond ownership. Holding executive positions in the firm or company group enhances the family member's ability to monitor non-financial operations, such as corporate philanthropy, and fulfill their stewardship role (Davis et al., 1997; Henssen, Voordeckers, Lambrechts, \& Koiranen, 2014, Wasserman, 2006). A physically attractive CEO who is a family member is likely to experience conflict because the CEO may personally favor inequality, however, the family stewardship values implying need to sustain business in the long run may force the CEO to show stewardship behavior through philanthropic activities. Thus, again the impact of low egalitarian values of a physically attractive CEO on corporate philanthropy would be diminished, if the CEO is a family member (Miller, Breton-Miller, \& Scholnick, 2008). The outsider CEO, on the contrary, has a much lower burden of business continuity and may try to maximize immediate financial incentives through competitive rather than egalitarian strategies. 
Family CEOs have been found to show positive steward behavior, and this behavior has influenced firms' survival (Vallejo, 2009) and financial performance (Kellermanns \& Eddleston, 2007) as well as employees' trust and commitment (Davis, Allen, \& Hayes 2010). Overall, the obligation to adopt family-imposed altruistic values, hence contributing toward philanthropy, would be greater for family CEOs than non-family CEOs. Consequently, when a physically attractive CEO is not a family member, impact of low egalitarian values of a physically attractive CEO on philanthropic contributions would be more adverse. Hence, we hypothesize:

Hypothesis 3. CEO facial attractiveness has a conditional indirect effect on corporate philanthropy through egalitarian values, where the mediation impact of egalitarianism is moderated by CEO type, such that the indirect effect of CEO physical attractiveness on corporate philanthropy is more negative when the CEO is a non-family member.

\section{Data and Method}

\section{Sample and Data Collection}

Data was collected for the Group "A" and Group "B" listed Indian firms on Bombay Stock Exchange (BSE). According to the criterion set by BSE, firms listed under group A and B categories need to score well on parameters such as market capitalization, turnover and corporate governance reporting. Furthermore, we did not consider banks, foreign owned and public-sector units. Excluding these firms, resulted in a list of 1401 firms which belonged either to Group A or Group B. Financial data for the firms was collected for a period of three years, i.e., from 20142016 from the financial database, Prowess of the Centre for Monitoring Indian Economy.

In the present study, we required the images of the CEOs to calculate the facial beauty or attractiveness scores of the CEOs. Thus, another major reason for considering Group A and Group B firms was that due to their performance implications, these firms were more likely to be covered 
by the media, thus chances of availability of appropriate images of a CEO were high. Also, since Indian firms are dominated by male CEOs, to avoid any sample biasness, we also removed all the firms with a woman CEO. To measure the facial attractiveness of the CEOs we used Anaface, which is a web-based facial image application software and freely available from www.anaface.com. Recently several scholars have relied on this software to examine the facial attractiveness of executives and other targets (Halford \& Hsu, 2014; Hoegele, Schmidt, \& Torgler, 2016; Ling, Luo, \& She, 2016). Next, two postgraduate students from a UK university independently searched for the availability of images of the CEOs from firms in the Group A and Group B categories. Following Hoegele et al. (2016) for each CEO the students searched for two images with sufficient resolution, face looking directly at the camera and visibility of facial landmarks. These three criteria are also the major requirements to obtain accurate facial beauty scores when using Anaface. The students obtained the images of the CEOs by searching across company websites, annual reports, LinkedIn, Google Search, Google Images, and Google News. Only those CEOs and their images were considered on which both the students had an exact agreement about the appropriateness of the images. After filtering firms based on the abovementioned criterion, and also eliminating firms with incomplete financial information on variables considered in the study, we were left with a sample of 647 firms, thus giving us data points for $647 * 3$ years $=1941$ firm years and 659 pairs of images for each student (as there were 12 CEO replacements in our sample). Depending on the variable, information was obtained from CMIE prowess (financial database of Indian firms), annual reports of the firm, company's website, Bloomberg, Wallmine, MarketScreener, Google and Yahoo images among online sources. 


\section{Dependent Variable.}

Corporate Philanthropy: As philanthropy can be measured in several ways, we focused on firm's philanthropy as donations and investment in community development only, as they are most commonly used measures (Feliu \& Botero, 2016). We considered the natural log of the philanthropy to reduce variability in the data.

\section{Independent Variables}

Facial Attractiveness Index (FAI). The effect of facial attractiveness has been well explored in psychology literature based on ratings given by survey respondents (Cunningham,1986; Cunningham, Barbee, \& Pike, 1990; Cunningham, Roberts, Barbee, Druen, \& Wu, 1995). However, recently use of facial geometry to determine attractiveness has also gained pace. Following approaches of Schmid, Marx, and Samal (2008) and Halford and Hsu (2014), we calculate a facial attractiveness index (FAI) of CEOs from Anaface, which is a web-based image analysis application software. Anaface computes the facial beauty scores of a person based on facial geometry and does not consider eye, skin complexion or color of the skin (Halford \& Hsu, 2014). This application provides beauty scores on a scale of 1 to 10 with scores closer to 10 indicating higher facial attractiveness or beauty (Halford \& Hsu, 2014; Hoegele et al., 2016). The algorithm of Anaface is proprietary and it calculates the geometry of faces using neoclassical beauty, research papers and scientific studies (Halford \& Hsu, 2014). After an image is uploaded over anaface.com, the application allows for manually placing 17 different markers at different facial landmarks (refer to Figure 1). These markers help in calculating the overall beauty score of the uploaded image by considering the horizontal symmetry of the face, the ratio of eye width to innerocular distance, ratio of nose length to ear length, ratio of the nose width to mouth width, etc. 
Insert Figure 1 about here

To ensure reliability and validity (Halford \& Hsu, 2013; Hoegele et al., 2016) of the CEO facial attractiveness measure we followed a two-step procedure. First, two postgraduate students from a UK University, over a one-month period independently uploaded each of the CEO images over anaface.com six times and using the 17 markers obtained six facial beauty scores for all the $893 * 2=$ 1786 images. Next, we calculated the average facial beauty score value for each CEO image across both the students. Thus, two average beauty score values were generated corresponding to each of the CEOs, for whom then the grand average was taken for each CEO. Correlation between facial beauty scores as calculated by the two postgraduate students was 0.92 .

Family Ownership Concentration (FOC). This was captured as the percentage of equity owned by the family in a firm.

CEO Type. To identify a family CEO, the name of the CEO or Managing Director considered in the present study was cross-checked with the promoter shareholding list available at the BSE website. If the CEO's name appeared in the promoting shareholder list, it was marked as one else zero (La Porta \& Lopez-de-Silanes, 1999).

Egalitarian values (CEO Pay gap). We calculated egalitarian values with vertical pay gap and horizontal pay gap. Vertical pay gap was calculated as the ratio of CEO pay and the average pay of TMT members, excluding CEO, such that a higher pay ratio reflected lesser egalitarian values (Siegel \& Hambrick, 2005). Horizontal pay gap was measured by coefficient of variation in the total pay of TMT members other than CEO. The coefficient of variation was calculated by dividing 
the standard deviation of group members' compensation by the mean compensation of the group (Siegel \& Hambrick, 2005).

Interaction effect of Family Ownership Concentration and CEO Pay Gap (FOC *CEO Pay Gap). To calculate interaction effect, we mean centered both the variables, i.e., scores of CEO Pay Gap and ownership concentration of family and then multiplied the obtained values from each other. Mean centering was performed to reduce the chances of multicollinearity (Shieh, 2010). We considered both horizontal and vertical pay gap for interaction effects.

Interaction effect of CEO Type and CEO Pay Gap (CEO Type* CEO Pay Gap). We mean centered both the scores of CEO Pay Gap and the family CEO variable and multiplied the values with each other to calculate the interaction effect. We considered both horizontal and vertical pay gap for interaction effects.

\section{Control Variables}

To eliminate any errors pertaining to the measurement of FAI, we also controlled for CEO facial image characteristics like smiling face, baldness, eyeglasses and color of the photograph using dummy variables. When the CEO image had eyeglasses, it was coded as 0 , else 1 . Similarly, smiling face was coded as 0 , else 1 . Colored photograph was 1 , else 0 . Bald head including forehead bald head was coded as 0 , else 1 . Some of the demographic traits of a CEO such as education and tenure in an organization could also influence the level of corporate philanthropy. Thus, we controlled for these factors as well. For education, business education can make individuals specifically sensitive towards philanthropy and related issues (Manner, 2010). Thus, if a CEO had MBA degree, then the education of the CEO was coded as 1 , else 0 . Similarly, the tenure of the CEO in the organization could also influence attitude toward philanthropic activities 
(Huang, 2013). Hence, we calculated the natural log of total number of years a CEO has been associated with an organization. Apart from this, other permanent physical dimensions of facial appearance such as facial-width-to-height ratio (fWHR) may also influence philanthropic giving by CEO (Geniole, Molnar, Carré, \& McCormick, 2014). Hence, we controlled for this construct as well. fWHR was measured as the distance between the two zygions relative to the distance between the upper lip and the highest point of the eyelid. Open source, ImageJ software was used to measure height of upper face (the distance between the lip and brow) as well as the bizygomatic width (left and right zygion) of the images. From these two values, ratio of facial width to height was calculated (Hahn et al., 2017). Apart from this we also controlled for skin tone as skin color may influence facial attractiveness. Skin tone may vary from dark to brown to fair. Again, two postgraduate students at a UK university rated each CEO on a scale of 1 to 5 for the skin tone, where 1 stood for very dark and 5 represented very fair. Average of the two ratings received for each CEO was taken as a measure of the skin color of the CEO. Correlation between rating given by the two raters was 0.89 .

Apart from this several organization level variables could also influence corporate philanthropy such as slack available with the organization, its past performance, firm age, and size of the firm. Thus, we controlled for these variables as well. Industry effects were also controlled for.Slack was measured as cash in hand. Past performance was measured as Return on Assets (ROA). Firm age was calculated as the natural logarithm of the total number of years since the time of the firm's inception. The size of the firm was calculated as the natural logarithm of the total number of employees. Natural logarithm was used to reduce variability in variables. Similarly, we also controlled for revenues of the firm by taking natural log of the values. 


\section{Estimation Strategy}

To test hypotheses $1 \mathrm{a}, 1 \mathrm{~b}$ and $1 \mathrm{c}$ we conducted regression analysis followed by mediation analysis. For mediation analysis, we used Model 4 of the Process macro (Version 3.4) (Hayes, 2018). In this model, corporate philanthropy was the outcome variable, CEO Pay gap (egalitarian values) was the mediating variable and FAI was the predictor variable. To test hypotheses 2 and 3, moderated-mediation models were employed using the Model 14 of the Process Macro. Figure 2 presents the three models.

Insert Figure 2 about here

Following a similar strategy as employed by Buckley and Tian (2017), we employed a bootstrapping approach for conducting the mediation analysis and the two moderated-mediation analyses. According to Preacher et al. (2007) and Hayes (2018), bootstrapping is at present one of the most reliable approach for mediation analysis. A bootstrapping re-sample value of 1,000 was used for all the three models (Hayes, 2018). Using White's heteroskedastic-consistent standard errors, all the estimates were corrected for heteroskedasticity. We initially ran a base model (Model 0) with all variables and corporate philanthropy, as the outcome variable. Subsequently, mediation analysis was conducted followed by the two moderated-mediation models.

\section{Results}

Table 1 presents the descriptive statistics and correlation coefficients for the sample of 1941 firm years. As can be observed from Table 1 the average facial attractiveness was 7.2 with a standard deviation of 1.24. Previous studies conducted in developed markets with Anaface also reported 
similar facial attractiveness scores (Halford \& Hsu, 2014). However, we also conducted a robustness test as explained below, where a primary study was conducted in the Indian market to assess the validity and reliability of the software. Furthermore, the correlation coefficient between the facial attractiveness index of CEO and corporate philanthropy was found to be negative and significant $(\mathrm{r}=-0.31, \mathrm{p}<0.001)$, thus signaling some preliminary evidence for physical attractiveness and corporate philanthropy relationship.

Insert Table1 about here

Table 2 presents results of the regression and mediation analysis. First, we employ a base model (Model 0) to test the relationships between the control variables, the independent variable and corporate philanthropy. Column 1 of Table 2 presents the results of the main regression analysis. The beta coefficients of cash-in-hand $(\beta=0.181, \mathrm{p}<0.01)$ and revenues $(\beta=0.218$, $\mathrm{p}<0.01)$ were positive and significant among control variables.

Next, we employ a mediation analysis to test hypotheses $1 \mathrm{a}, 1 \mathrm{~b}$ and $1 \mathrm{c}$. Through hypothesis 1a we speculated that egalitarian values of CEO negatively affected corporate philanthropy whilst through hypothesis $1 \mathrm{~b}$ we speculated that corporate philanthropy is negatively associated with facial attractiveness of CEO. Through hypothesis $1 \mathrm{c}$ we asserted that CEO Pay gap (egalitarian values) mediated this relationship. As can be observed from column 4 of Table 2, the coefficients of both vertical and horizontal pay gap (egalitarian values) on corporate philanthropy were negative and significant ( $\beta$ Vertical Pay Gap $\left.=-0.127, \mathrm{p}<0.001 ; \beta_{\text {Horizontal Pay Gap }}=-0.116, \mathrm{p}<0.001\right)$, lending support to hypothesis 1a. Next, from column 1 in Table 2 we observe that the coefficient 
of FAI on is negative and significant $(\beta=-0.056, p<0.001)$. This lends support to H1b. Finally, from columns 1 and 2 in Table 3, we observe that the indirect effect of FAI on corporate philanthropy through CEO vertical and horizontal pay was negative and statistically different from zero $\left(\theta_{\text {Vertical Pay Gap }}=-0.0485 ; \mathrm{LCI}=-0.0520 ; \mathrm{UCI}=-0.0389 ; \theta_{\text {Horizontal Pay Gap }}=-0.0361 ; \mathrm{LCI}=-0.0392\right.$; $\mathrm{UCI}=-0.0297)$. Overall, these implied a support for Hypothesis $1 \mathrm{c}$.

Insert Table 2 about here

Insert Table 3 about here

To test hypotheses 2 and 3, we ran four moderated-mediation analyses, one involving FOC as a moderator affecting the relationship between CEO Pay gap (vertical and horizontal) and corporate philanthropy and other having CEO Type as a moderator affecting the same relationship. Table $4 \mathrm{a}$ and $4 \mathrm{~b}$ present the results of the moderated mediation analysis. In Table $5 \mathrm{a}$ and $5 \mathrm{~b}$, we present the coefficient for the indirect effect of FAI on corporate philanthropy through CEO Pay gap (vertical and horizontal) for different levels of FOC and also for different levels of CEO Type.

Insert Table 4a about here 
Insert Table $4 \mathrm{~b}$ about here

Insert Table 5a about here

Insert Table $5 \mathrm{~b}$ about here

Hypothesis 2 stated that CEO facial attractiveness has a conditional indirect effect on corporate philanthropy through CEO Pay gap (egalitarian values), where the mediation effect of CEO Pay gap is moderated by family ownership concentration, such that the indirect effect of CEO physical attractiveness on corporate philanthropy is more negative when FOC is low. From column 1 of Table 4a, we can observe the beta coefficient of the interaction term of CEO Pay Gap (Vertical) and FOC on philanthropy was positive and significant $(\beta=0.061, \mathrm{p}<0.001)$ as well as the interaction term of CEO Pay Gap (Horizontal) and FOC was positive and significant $(\beta=0.049$, $\mathrm{p}<0.001$ ). Column 1 of Table 5a, suggests that indirect effect of FAI on philanthropy, mediated by vertical pay gap, was more negative and statistically significant at low level of FOC $(\theta=-0.0325$; $\mathrm{LCI}=-0.0362 ; \mathrm{UCI}=-0.0288)$ than at anerage level of FOC $(\theta=-0.0258 ; \mathrm{LCI}=-0.0279 ; \mathrm{UCI}=-$ $0.0228)$ and a high level of FOC $(\theta=-0.0188$; $\mathrm{LCI}=-0.0225$; UCI $=-0.0137)$. Specifically, a $1 \%$ increase in FAI, led to decline of $0.0325 \%, 0.0258 \%$ and $0.018 \%$ in corporate philanthropy. 
Similarly, for horizontal pay gap also as depicted in column 1 of Table $5 \mathrm{~b}$, indirect effect of FAI on philanthropy was more negative and statistically significant at low level of FOC $(\theta=-$ 0.0292; $\mathrm{LCI}=-0.0318 ; \mathrm{UCI}=-0.0264)$ than at an average level of $\mathrm{FOC}(\theta=-0.0236 ; \mathrm{LCI}=-0.0256$; $\mathrm{UCI}=-0.0221)$ and a high level of $\mathrm{FOC}(\theta=-0.0179 ; \mathrm{LCI}=-0.0211 ; \mathrm{UCI}=-0.0138)$. We thus receive evidence in support of hypothesis 2 .

Through hypothesis 3 we speculated that CEO facial attractiveness has a conditional indirect effect on corporate philanthropy through CEO Pay gap, where the mediation effect of CEO Pay gap is moderated by CEO Type, such that the indirect effect of CEO physical attractiveness on corporate philanthropy is more negative when the CEO is not a family member. From column 1 of Table 4b, we observe the interaction term of CEO Pay Gap (Vertical) and CEO Type on philanthropy was positive and significant $(\beta=0.052, \mathrm{p}<0.001)$ as well as the interaction term of CEO Pay Gap (Horizontal) and CEO Type was positive and significant $(\beta=0.043$, $\mathrm{p}<0.001)$.

Further, column 2 of Table $5 \mathrm{a}$ and $5 \mathrm{~b}$ reveals that the indirect effect of FAI on corporate philanthropy was more negative and significant when CEO was not a family member for both vertical as well as horizontal pay gap respectively $\left(\theta_{\text {Vertical }}=-0.0338 ; \mathrm{LCI}=-0.0371 ; \mathrm{UCI}=-0\right.$. 0.0263), ( $\left.\theta_{\text {Horizontal }}=-0.0300 ; \mathrm{LCI}=-0.0326 ; \mathrm{UCI}=-0.0255\right)$ than when the $\mathrm{CEO}$ was a family member $\left(\theta_{\text {Vertical }}=-0.0196 ;\right.$ LCI $\left.=-0.0210 ; \quad \mathrm{UCI}=-0.0149\right) ; \quad\left(\theta_{\text {Horizontal }}=-0.0182 ; \mathrm{LCI}=-0.0207\right.$; UCI $=-0.0146$ ). Specifically, a $1 \%$ increase in FAI, led to a $0.0338 \%$ and a $0.0196 \%$, decrease in philanthropy, through CEO pay when the CEO was a non-family member and when the CEO was a family member respectively for vertical pay gap. For horizontal pay gap, a $1 \%$ increase in FAI, led to a $0.0300 \%$ and a $0.018 \%$, decrease in philanthropy, through CEO pay when the CEO was a 
non-family member and when the CEO was a family member respectively. Overall, hypothesis 3 is supported.

\section{Robustness Test}

We conducted five robustness tests, with two tests related to the measurement of FAI, one test related to the measurement of corporate philanthropy, a test incorporating the change in corporate philanthropy law in India and a test introducing TMT size as an alternate moderator.

\section{Test 1}

To further confirm the validity of CEO attractiveness measures, following extant literature (Halford \& Hsu, 2014; Hoegele et al., 2016) we conducted a primary survey in India. We selected Indian respondents as due to skin color, opinion in developed countries could have been biased. First, we randomly selected 50 CEOs out of the 273 CEOs considered in the secondary study. Next 180 consumers from a Tier 1 and a Tier 2 city in India were invited to participate in this study. Only 147 consumers (Females $=72$ ) accepted the invitation to participate in the study. All the respondents through email received an online questionnaire link for completing the survey. Each page of the questionnaire had a CEO image. Against each CEO image, a five-point rating scale with one being the least attractive and five being the most attractive (Halford \& Hsu, 2014) was provided. Only 128 respondents returned the questionnaire out of which six were removed from further analysis because of missing information. Thus, data of 122 respondents $($ Females $=59)$ was subjected to further analysis. The median age of the respondents was 29 years, and the mean annual income was $\$ 7,150$. Furthermore 72 respondents were from a Tier 2 city of India and the remaining were from a Tier 1 city. The Facial Attractiveness Index was positively and significantly correlated $(\mathrm{r}=0.37, \mathrm{p}<0.01)$ with the survey-based attractiveness measure in the correlation test. 


\section{Test 2}

To examine the consistency of respondent's rating, we also showed images of trial subjects who were unrelated to the CEO sample and asked respondents to rate them as well. Subjects who resembled fashion models received higher attractiveness ratings ranging from 7.9 to 8.6 than those with average looks whose values ranged from 6.3 to 7.5 .

\section{Test 3}

Philanthropy Deviation: The Indian government in 2014 mandated that firms earning profits of more than 78 million dollars need to contribute two percent of profits towards philanthropic cause. To ensure that philanthropic needs were not purely driven by law, we subtracted corporate philanthropic donations made by the firm each year from the expected amount based on profits earned, as mandated by government. Thus, instead of corporate philanthropic donations, we considered level of deviation from expected donations as mandated by government. Using these values, we again ran the same regression, keeping all independent and control variables same. Although value of beta coefficients changed, however, overall, their significance did not change thus leading to acceptance of all our hypothesis.

\section{Test 4}

Total Philanthropy: We also included the expenditure on environmental and pollution control by a focal firm as part of corporate philanthropy. Though the values of beta coefficients changed, results remained statistically significant.

\section{Test 5}

TMT size as moderator: We tested the role of TMT size as an alternate moderator in addition to FOC and CEO Type. The influence of TMT size as a moderator was found to be significant. As we were exploring a new dimension of upper echelon theory i.e. identifying personal values 
through physical traits rather than demographic traits, it was vital to control for CEO-TMT interphase (Heyden et al, 2017). Since TMT size is the most commonly used variable, we controlled for the same.

\section{General Discussion \& Conclusion}

Can CEO's physical attractiveness make a difference in the level of philanthropy that a corporate indulges into? In this study, we examine this issue and further explore how this relationship between FAI and corporate philanthropy is moderated mediated by egalitarianism as a mediator and family ownership and control as moderators in emerging markets. We thus document the effect of CEO's physical attractiveness on philanthropy by integrating empirical findings in the field of psychology related to egalitarian values and physical attractiveness with philanthropy literature. Through our first hypothesis, we find that physically attractive CEOs were less likely to be egalitarian. Through our second hypothesis we found that less egalitarian CEOs invested less in philanthropic activities, at least in the Indian context. Through our third hypothesis we found that egalitarian values mediated this relationship. However, our findings do not imply that FAI is overall positively or negatively related to corporate philanthropy, as we only examined two mediating paths via vertical and horizontal CEO pay gaps, moderated by family ownership concentration and family CEO.

Extant literature indicates that the leader's physical appearance influences several individual and firm level outcomes such as leader's compensation (Graham, Harvey, \& Puri, 2016), or negotiating power (Haselhuhn, Wong, Ormiston, Inesi, \& Galinsky 2014), risk taking ability (Welker, Goetz, \& Carré, 2015), aggressive behavior (Goetz et al., 2013), personal lending (Duarte, Siegel, \& Young, 2012; Ravina, 2012), hedge fund investments (Pareek \& Zuckerman, 2013), financial misreporting (Jia, Lent, Ravina \& Zeng, 2014), unethical behavior (Geniole et al., 
2014), firm's performance (Pillemer, Graham, \& Burke, 2014; Rule \& Tskhay, 2014), and competitive performance (Tsujimura \& Banissy, 2013; Trichas, Schyns, Lord, \& Hall, 2017). Our findings corroborate with extant literature, where physical attractiveness influences corporate philanthropy.

Furthermore, we test the relationship between philanthropy and CEO's physical attractiveness under the boundary condition as set by family ownership and control. Using stewardship theory, we asserted that due to the sustainability issue of businesses, especially in a country with institutional voids, it was vital for family members to gain long-term trust and reputation amongst external stakeholders. Philanthropic activities provide an opportunity for family businesses to achieve this goal. Thus, as their ownership concentration increased, they were better able to exercise control and make the CEO abide by family values and mission, which dampened the effect of personal egalitarian values on corporate philanthropy. Our findings extend the past literature on corporate philanthropy where family firms were found to have a positive impact on philanthropy (Campopiano et al., 2014; Du, 2017; Lamb \& Butler, 2018; Laguir, Laguir, \& Elbaz, 2016). Similarly, TMT size, though in a robustness study, was also found to moderate the relationship. Furthermore, relationships remained robust with alternative measures of corporate philanthropy as well.

This study makes the following contributions to corporate philanthropy, upper echelon, and family business literature. First, we add to the corporate philanthropy literature by examining the influence of egalitarian values through physical attractiveness of CEOs, on philanthropy. Individual-level drivers of corporate philanthropy have largely focused on the business case of philanthropy by virtue of profit maximization or utility maximization perspective (Gautier \& Pache, 2014). Our study adds to this aspect of philanthropy, where the underlying egalitarian 
values of CEOs mediated the relationship between CEO facial attractiveness and philanthropic behavior. Our findings assert that the physical attractiveness of a CEO is negatively associated with philanthropic activities.

Second, although several drivers of corporate philanthropy have been explored, they have either focused on firm-level factors (Adams, Hoejmose, \& Kastrinaki, 2017; Li, Song, \& Wu, 2015) or individual-level factors (Raub, 2017). Studies exploring the integrative effect of individual and firm-level factors are scant, despite scholars urging the need for the same (Gautier \& Pache, 2015). Our study is a step in this direction. We explore the impact of an individual level factor, i.e. CEO's physical attractiveness under the boundary condition of CEO pay gap mediation made more nuanced by the firm-level moderating factors like family ownership concentration and control by family. In this regard, we also establish the role of CEO egalitarianism as a mediator and extend the literature on CEO egalitarian values. The extant literature suggests CEOs' political ideology impacts their vertical compensation pay gap (Chin \& Semadeni, 2017). Our findings add to this stream of literature by asserting that physically attractive CEOs also have less egalitarian values. Furthermore, extant studies from developed markets present mixed results about the stewardship behavior of family businesses. Some studies have found a positive impact of ownership by family firms (Campopiano et al., 2014; Dyer \& Whetten, 2006), while others claimed a negative impact (Morck \& Yeung, 2004). The present study adds to the ongoing debate on the social behavior of family firms by exploring its moderating impact on mediated relationship, thus further enhancing evidence of family business philanthropy.

Third, we contribute to the upper echelon literature. Scholars have generally considered demographic traits such as CEOs' education to explain differences in philanthropy across firms (Hemingway \& Maclagan, 2004). However, demographic traits were criticized as they assumed 
certain intervening processes, which were not proved (Priem, Lyon, and Dess, 1999, p. 936). By incorporating role of physical attractiveness, we not only extend boundaries of demographic traits of CEO in philanthropy context, but by virtue of theoretically banking on empirically established intervening process i.e. egalitarian values that affects philanthropic decisions, we try to resolve this black box phenomenon at least to some extent by empirically testing the mediating role of CEOs' egalitarian values and find evidence for the same.

\section{Managerial Implications}

Today, several Indian firms are keen on hiring CEOs who value not only profit but social contributions as well. The study presents a major milestone for the board of directors and stakeholders at large who through our study are encouraged to consider philanthropy dynamics that exist in their firms and reconsider recruitment of physically attractive CEOs who otherwise provide financial benefits to the firm through higher market valuation (Graham et al., 2016). Companies are increasingly moving towards a sustainable growth model, and attractive CEOs can make this task difficult because of their low egalitarian values for philanthropy. Overall, physical attractiveness of a CEO, can help boards of directors and stakeholders at large to appoint an appropriate CEO who genuinely believes in philanthropy.

Although physically attractive CEOs can enhance firm's perceived performance, overall, they can have an adverse influence on a firm's reputation due to poor egalitarian attitude towards philanthropic initiatives. Furthermore, although appointing family members in the top management team has often been charged with the adverse effect of nepotism, at least for sustainable businesses physically attractive family CEOs are more likely to abide by steward values and hence do not deter philanthropic activities, compared to non-family CEOs. Lastly, as ownership concentration of family members decreases, a physically attractive CEO is more likely 
to exercise his personal values at least in the context of philanthropy. Thus, family members with a low ownership concentration need to identify ways to fulfill the non-economic goals of the business, if they hire physically attractive CEOs. Boards can also encourage large size TMTs as in the presence of large TMTs, physically attractive CEOs may be unable to exercise their low egalitarian values through less philanthropic contributions.

\section{Limitations and Directions for Future Research}

Though we make significant contributions, yet our study suffers from several limitations, which paves way for future research. First, we do not empirically examine the underlying egalitarian value of a CEO, while explaining the physical attractiveness and philanthropy relationship. Though, we rely on the extant psychology literature explaining that physically attractive individuals have lower egalitarian values (Price et al., 2015; 2011), future studies in the corporate context could benefit by directly measuring such values of CEOs through primary studies. Second, for defining physical attractiveness, we leverage only on facial beauty, whereas overall personality could also influence the egalitarian mindset. Although we focus only on facial attractiveness following the extant literature, future studies should explore the same phenomenon using overall personality as an attractiveness measure. Third, the software considers only innerocular distances and not skin color. However, skin color could also influence facial attractiveness, thus future studies could conduct the studies taking skin color into consideration also. Fourth, we conduct the study in only one of the emerging markets. Future studies could explore if similar results are obtained in developed markets as well or what cultural values could create differences in the philanthropic activities of CEOs. Future research can also explore further family business dynamics and how they create boundary conditions for physical attractiveness of CEO and philanthropy relationship. For instance, founder CEOs may have more stewardship values, 
however, such values may get diluted from generation to generation (Berrone, Cruz, \& GomezMejia, 2012; Gomez-Mejia, Cruz, Berrone, \& De Castro, 2011), leading to a stronger impact of physical beauty on corporate philanthropy. Similarly, more distant family members may not share similar stewardship values as close family members. Similarly, the interplay between demographics, personality, and physical appearance of the CEO can be studied in the context of corporate philanthropy. Lastly, the upper echelon theory explains the impact of several traits of CEO on philanthropy. However, physical attractiveness of CEO could also influence these relationships, which could be explored in future studies. 


\section{Compliance with Ethical Standards:}

All procedures performed in studies involving human participants were in accordance with the ethical standards of the institutional research committee and with the 1964 Helsinki declaration and its later amendments or comparable ethical standards.

Informed consent: Informed consent was obtained from all individual participants included in the study. 


\section{Reference}

Adams, M., Hoejmose, S., \& Kastrinaki, Z. (2017). Corporate philanthropy and risk management: An investigation of reinsurance and charitable giving in insurance firms. Business Ethics Quarterly, 27(1), 1-37.

Amason, A. C., \& Sapienza, H. J. (1997). The effects of top management team size and interaction norms on cognitive and affective conflict. Journal of Management, 23(4), 495-516.

Amato, L. H., \& Amato, C. H. (2012). Retail philanthropy: Firm size, industry, and business cycle. Journal of Business Ethics, 107(4), 435-448.

Anderson, R. C., \& Reeb, D. M. (2003). Founding-family ownership and firm performance: evidence from the S\&P 500. Journal of Finance, 58(3), 1301-1328.

Arneson, R. (2002). Egalitarianism, in: Zalta, N. (ed.): The Stanford Encyclopedia of Philosophy. [Cited 17 January, 2019]. Available from URL: https://seop.illc.uva.nl/entries/egalitarianism/ Arrègle, J. L., Hitt, M. A., Sirmon, D. G., \& Very, P. (2007). The development of organizational social capital: Attributes of family firms. Journal of Management Studies, 44(1), 73-95.

Banducci, S. A., Karp, J. A., Thrasher, M., \& Rallings, C. (2008). Ballot photographs as cues in low-information elections. Political Psychology, 29(6), 903-917.

Ballew, C. C., \& Todorov, A. (2007). Predicting political elections from rapid and unreflective face judgments. Proceedings of the National Academy of Sciences, 104(46), 17948-17953.

Berrone, P., Cruz, C., \& Gomez-Mejia, L. R. (2012). Socioemotional wealth in family firms: Theoretical dimensions, assessment approaches, and agenda for future research. Family Business Review, 25(3), 258-279. 
Breeze, B. (2009). Natural philanthropists: Findings of the family business philanthropy and social responsibility inquiry. Institute for Family Business (UK). [Cited 17 January, 2019]. Available from URL: https://kar.kent.ac.uk/37241/

Brickley, J. A., Smith Jr, C. W., \& Zimmerman, J. L. (1997). Management fads and organizational architecture. Journal of Applied Corporate Finance, 10(2), 24-39.

Bobo, L. (1991). Social responsibility, individualism, and redistributive policies. In Sociological Forum (Vol. 6, No. 1, pp. 71-92). Kluwer Academic Publishers-Plenum Publishers.

Buchholtz, A. K., Amason, A. C., \& Rutherford, M. A. (1999). Beyond resources: The mediating effect of top management discretion and values on corporate philanthropy. Business \& Society, $38(2), 167-187$.

Buckley, P. J., \& Tian, X. (2017). Transnationality and financial performance in the era of the global factory. Management International Review, 57(4), 501-528.

Calabrese, T. (2013). Running on empty: The operating reserves of US nonprofit organizations. Nonprofit Management and Leadership, 23(3), 281-302.

Campopiano, G., De Massis, A., \& Chirico, F. (2014). Firm philanthropy in small-and mediumsized family firms: The effects of family involvement in ownership and management. Family Business Review, 27(3), 244-258.

Centre issues notice to 300 firms not complying with CSR norm. (2018, November 7). Financial Express. [Cited 17 January, 2019]. Available from URL: https://www.financialexpress.com/economy/centre-issues-notice-to-300-firms-not-complyingwith-csr-norm/1375014/

Chen, X., Cheng, Q., \& Dai, Z. (2013). Family ownership and CEO turnovers. Contemporary Accounting Research, 30(3), 1166-1190. 
Chin, M. K., Hambrick, D. C., \& Treviño, L. K. (2013). Political ideologies of CEOs: The influence of executives' values on corporate social responsibility. Administrative Science Quarterly, 58(2), 197-232.

Chin, M. K., \& Semadeni, M. (2017). CEO political ideologies and pay egalitarianism within top management teams. Strategic Management Journal, 38(8), 1608-1625.

Choi, J., \& Wang, H. (2007). The promise of a managerial values approach to corporate philanthropy. Journal of Business Ethics, 75(4), 345-359.

Claessens, S., Djankov, S., Fan, J. P., \& Lang, L. H. (2002). Disentangling the incentive and entrenchment effects of large shareholdings. The Journal of Finance, 57(6), 2741-2771.

Cunningham, M. R. (1986). Measuring the physical in physical attractiveness: Quasi-experiments on the sociobiology of female facial beauty. Journal of Personality and Social Psychology, 50(5), 925-935.

Cunningham, M. R., Barbee, A. P., \& Pike, C. L. (1990). What do women want? Facialmetric assessment of multiple motives in the perception of male facial physical attractiveness. Journal of Personality and Social Psychology, 59(1), 61-72.

Cunningham, M. R., Roberts, A. R., Barbee, A. P., Druen, P. B., \& Wu, C. H. (1995). " Their ideas of beauty are, on the whole, the same as ours": Consistency and variability in the cross-cultural perception of female physical attractiveness. Journal of Personality and Social Psychology, 68(2), 261-279.

Davis, J. H., Allen, M. R., \& Hayes, H. D. (2010). Is blood thicker than water? A study of stewardship perceptions in family business. Entrepreneurship Theory and Practice, 34(6), 1093 1116. 
Davis, J. H., Schoorman, F. D., \& Donaldson, L. (1997). Toward a stewardship theory of management. Academy of Management Review, 22(1), 20-47

De Cremer, D., \& Van Lange, P. A. (2001). Why prosocials exhibit greater cooperation than proselfs: The roles of social responsibility and reciprocity. European Journal of Personality, 15(S1), S5-S18.

Dennis, B. S., Buchholtz, A. K., \& Butts, M. M. (2009). The nature of giving: A theory of planned behavior examination of corporate philanthropy. Business \& Society, 48(3), 360-384.

Donaldson, L., \& Davis, J. H. (1991). Stewardship Theory or Agency theory: CEO governance and shareholder returns. Australian Journal of Management, 16 (1), 49-64.

Du, X. (2017). Religious belief, corporate philanthropy, and political involvement of entrepreneurs in Chinese family firms. Journal of Business Ethics, 142(2), 385-406.

Duarte, J., Siegel, S., \& Young, L. (2012). Trust and credit: The role of appearance in peer-topeer lending. The Review of Financial Studies, 25(8), 2455-2484.

Dyer, W. G., \& Whetten, D. A. (2006). Family firms and social responsibility: Preliminary evidence from the S\&P 500. Entrepreneurship Theory and Practice, 30(6), 785-802.

Eagly, A. H., Ashmore, R. D., Makhijani, M. G., \& Longo, L. C. (1991). What is beautiful is good, but...: A meta-analytic review of research on the physical attractiveness stereotype. Psychological Bulletin, 110(1), 109.

Feingold, A. (1992). Good-looking people are not what we think. Psychological Bulletin, 111(2), 304-341.

Feliu, N., \& Botero, I. C. (2016). Philanthropy in Family Enterprises: A Review of Literature. Family Business Review, 29(1), 121-141. 
Fox, M. A., \& Hamilton, R. T. (1994). Ownership and diversification: Agency theory or stewardship theory. Journal of Management Studies, 31(1), 69-81.

Gautier, A., \& Pache, A. C. (2015). Research on corporate philanthropy: A review and assessment. Journal of Business Ethics, 126(3), 343-369

Geniole, S. N., Molnar, D. S., Carré, J. M., \& McCormick, C. M. (2014b). The facial widthtoheight ratio shares stronger links with judgments of aggression than with judgments of trustworthiness. Journal of Experimental Psychology: Human Perception and Performance, 40(4), $1526-1541$

Goetz, S. M., Shattuck, K. S., Miller, R. M., Campbell, J. A., Lozoya, E., Weisfeld, G. E., \& Carré, J. M. (2013). Social status moderates the relationship between facial structure and aggression. Psychological Science, 24(11), 2329-2334.

Gomez-Mejia, L. R., Cruz, C., Berrone, P., \& De Castro, J. (2011). The bind that ties: Socioemotional wealth preservation in family firms. Academy of Management Annals, 5(1), 653707.

Graham, J. R., Harvey, C. R., \& Puri, M. (2016). A corporate beauty contest. Management Science, 63(9), 3044-3056.

Grammer, K., Fink, B., Møller, A. P., \& Thornhill, R. (2003). Darwinian aesthetics: sexual selection and the biology of beauty. Biological Reviews, 78(3), 385-407.

Grammer, K., \& Thornhill, R. (1994). Human (Homo sapiens) facial attractiveness and sexual selection: the role of symmetry and averageness. Journal of Comparative Psychology, 108(3), 233-242. 
Gupta, A., Briscoe, F., \& Hambrick, D. C. (2018). Evenhandedness in resource allocation: Its relationship with CEO ideology, organizational discretion, and firm performance. Academy of Management Journal, 61(5), 1848-1868.

Habbershon, T. G. \& Williams, M. L. (1999). A resource-based framework for assessing the strategic advantages of family firms. Family Business Review, 12(1), 1-25.

Hahn, T., Winter, N. R., Anderl, C., Notebaert, K., Wuttke, A. M., Clément, C. C., \& Windmann, S. (2017). Facial width-to-height ratio differs by social rank across organizations, countries, and value systems. PloS One, 12(11), e0187957.

Haidt, J., \& Keltner, D. (2004). Appreciation of beauty and excellence [awe, wonder, elevation]. In C. Peterson \& M. E. P. Seligman (Eds.). Character strengths and virtues (pp. 537-551). New York, NY: Oxford University Press.

Halford, J. T., \& Hsu, S. H. (2014). Beauty is wealth: CEO appearance and shareholder value. SSRN. [Cited December 12, 2019]. Available at URL: from https://ssrn.com/abstract=2357756 or http://dx.doi.org/10.2139/ssrn.2357756

Hambrick, D. C., \& Mason, P. A. (1984). Upper echelons: The organization as a reflection of its top managers. Academy of Management Review, 9(2), 193-206.

Hambrick, D. C. (2007). Upper echelons theory: An update. Academy of Management Review, 32(2), 334-343.

Hamermesh, D. S., \& Biddle, J. E. (1994). Beauty and the labor market. American Economic Review, 84, 1174-94.

Haselhuhn, M. P., \& Wong, E. M. (2012). Bad to the bone: facial structure predicts unethical behaviour. Proceedings of the Royal Society B: Biological Sciences, 279(1728), 571-576. 
Haselhuhn, M. P., Wong, E. M., Ormiston, M. E., Inesi, M. E., \& Galinsky, A. D. (2014). Negotiating face-to-face: Men's facial structure predicts negotiation performance. The Leadership Quarterly, 25(5), 835-845.

Hayes, A. F. (2018). Introduction to mediation, moderation, and conditional process analysis: A regression-based approach. New York, NY: Guilford Publications.

Hemingway, C. A., \& Maclagan, P. W. (2004). Managers' personal values as drivers of corporate social responsibility. Journal of Business Ethics, 50(1), 33-44.

Henssen, B., Voordeckers, W., Lambrechts, F., \& Koiranen, M. (2014). The CEO autonomystewardship behavior relationship in family firms: The mediating role of psychological ownership. Journal of Family Business Strategy, 5(3), 312-322.

Hoegele, D., Schmidt, S. L., \& Torgler, B. (2016). The importance of key celebrity characteristics for customer segmentation by age and gender: Does beauty matter in professional football? Review of Managerial Science, 10(3), 601-627.

Holtzman, N. S., Augustine, A. A., \& Senne, A. L. (2011). Are pro-social or socially aversive people more physically symmetrical? Symmetry in relation to over 200 personality variables. Journal of Research in Personality, 45(6), 687-691.

Hooton, C. (May 2, 2014). Are you attractive? Anaface website claims to be able to determine whether you're beautiful. Independent. [ Cited 14 September 2019]. Available at URL: https://www.independent.co.uk/news/weird-news/are-you-attractive-anaface-website-claims-tobe-able-to-determine-whether-youre-beautiful-9316556.html

How India's New Philanthropists Are Working to Bring About Systemic Change. (2011, May 19). Knowledge @ Wharton. [Cited 12 January 2019]. Available at URL: 
http://knowledge.wharton.upenn.edu/article/how-indias-new-philanthropists-are-working-tobring-about-systemic-change/

Huang, S. K. (2013). The impact of CEO characteristics on corporate sustainable development. Corporate Social Responsibility and Environmental Management, 20(4), 234-244. Income inequality gets worse; India's top $1 \%$ bag $73 \%$ of the country's wealth, says Oxfam. (2019, January 30). Business Today. [Cited February 5, 2019]. Available at URL: https://www.businesstoday.in/current/economy-politics/oxfam-india-wealth-report-incomeinequality-richests-poor/story/268541.html

Jamali, D., \& Karam, C. (2018). Corporate social responsibility in developing countries as an emerging field of study. International Journal of Management Reviews, 20(1), 32-61.

Jia, Y., Lent, L. V., \& Zeng, Y. (2014). Masculinity, testosterone, and financial misreporting. Journal of Accounting Research, 52(5), 1195-1246.

Kellermanns, F. W., \& Eddleston, K. A. (2007). A family perspective on when conflict benefits family firm performance. Journal of Business Research, 60(10), 1048-1057.

Khanna, T., \& Palepu, K. (2000). Is group affiliation profitable in emerging markets? An analysis of diversified Indian business groups. The Journal of Finance, 55(2), 867-891.

King, A., \& Leigh, A. (2009). Beautiful politicians. Kyklos: International Review for Social Sciences, 62(4), 579-593.

Laguir, I., Laguir, L., \& Elbaz, J. (2016). Are family small-and medium-sized enterprises more socially responsible than nonfamily small-and medium-sized enterprises? Corporate Social Responsibility and Environmental Management, 23(6), 386-398.

Lamb, N. H., \& Butler, F. C. (2018). The influence of family firms and institutional owners on corporate social responsibility performance. Business \& Society, 57(7), 1374-1406. 
Lamin, A. (2013). Business groups as information resource: An investigation of business group affiliation in the Indian software services industry. Academy of Management Journal, 56(5), 14871509.

Langlois, J. H., Kalakanis, L., Rubenstein, A. J., Larson, A., Hallam, M., \& Smoot, M. (2000). Maxims or myths of beauty? A meta-analytic and theoretical review. Psychological Bulletin, $126(3), 390$.

La Porta, R., \& Lopez-de-Silanes, F. (1999). The benefits of privatization: Evidence from Mexico. The Quarterly Journal of Economics, 114(4), 1193-1242.

Le Breton-Miller, I., \& Miller, D. (2006). Why do some family businesses out-compete? governance, long-term orientations, and sustainable capability. Entrepreneurship Theory and Practice, 30(6), 731-746.

Lev, B., Petrovits, C., \& Radhakrishnan, S. (2010). Is doing good good for you? How corporate charitable contributions enhance revenue growth. Strategic Management Journal, 31(2), 182-200. Li, W., Au, K. Y. F., He, A., \& Song, L. (2015). Why do family-controlled firms donate to charity? The role of intrafamily succession intention, social status, and religiosity. Management and Organization Review, 11(4), 621-644.

Li, S., Song, X., \& Wu, H. (2015). Political connection, ownership structure, and corporate philanthropy in China: A strategic-political perspective. Journal of Business Ethics, 129(2), 399411.

Ling, L., Luo, D., \& She, G. (2016). Judging a Book by Its Cover: Beauty Effects in Chinese Communist Party's Internal Labor Market. In Academy of Management Proceedings (Vol. 2016, No. 1, p. 12803). Briarcliff Manor, NY 10510: Academy of Management. 
Manku, M. (2015, November 11). India least giving among South Asian nations. Live Mint. [Cited 12 January 2019]. Available

at

URL:

https://www.livemint.com/Politics/LQKIUgqJrvPHC3mcBSqgMO/India-least-giving-among$\underline{\text { South-Asian-n, ations.html }}$

Manner, M. H. (2010). The impact of CEO characteristics on corporate social performance. Journal of Business Ethics, 93(1), 53-72.

Miller, D., \& Le Breton-Miller, I. (2005). Managing for the long run: Lessons in competitive advantage from great family businesses. Boston, MA: Harvard Business Press.

Miller, D., Breton-Miller, L., \& Scholnick, B. (2008). Stewardship vs. stagnation: An empirical comparison of small family and non-family businesses. Journal of Management Studies, 45(1), $51-78$.

Morck, R. \& Yeung, B. (2004). Family control and the rent-seeking society. Entrepreneurship Theory and Practice, 28(4), 391-409.

Morrow, P. C. (1990). Physical attractiveness and selection decision making. Journal of Management, 16(1), 45-60.

Nathan, N. M. L. (1983). Egalitarianism. Mind: A Quarterly Review of Philosophy, 92(367), 413416.

Nedelec, J. L., \& Beaver, K. M. (2014). Physical attractiveness as a phenotypic marker of health: an assessment using a nationally representative sample of American adults. Evolution and Human Behavior, 35(6), 456-463.

Panwar, R., Paul, K., Nybakk, E., Hansen, E., \& Thompson, D. (2014). The legitimacy of CSR actions of publicly traded companies versus family-owned companies. Journal of Business Ethics, 125(3), 481-496. 
Pareek, A., \& Zuckerman, R. (2014). Trust and investment management: The effects of manager trustworthiness on hedge fund investments. SSRN. Retrieved October 21, 2017, from https://papers.ssrn.com/sol3/papers.cfm?abstract id=1659189

Peng, M. W., \& Jiang, Y. (2010). Institutions behind family ownership and control in large firms. Journal of Management Studies, 47(2), 253-273.

Petersen, M. B., Sznycer, D., Sell, A., Cosmides, L., \& Tooby, J. (2013). The ancestral logic of politics: Upper-body strength regulates men's assertion of self-interest over economic redistribution. Psychological Science, 24(7), 1098-1103.

Petrenko, O. V., Aime, F., Ridge, J., \& Hill, A. (2016). Corporate social responsibility or CEO narcissism? CSR motivations and organizational performance. Strategic Management Journal, 37(2), 262-279.

Pillemer, J., Graham, E. R., \& Burke, D. M. (2014). The face says it all: CEOs, gender, and predicting corporate performance. The Leadership Quarterly, 25(5), 855-864.

Praxmarer, S. \& Rossiter, J. R. (2009). How does the presenter's physical attractiveness persuade? A test of alternative explanations. Proceedings of the Australian and New Zealand Marketing Academy Conference (pp. 1-7). Melbourne, Australia: Australian \& New Zealand Marketing Academy.

Preacher, K. J., Rucker, D. D., \& Hayes, A. F. (2007). Addressing moderated mediation hypotheses: Theory, methods, and prescriptions. Multivariate Behavioral Research, 42(1), 185227.

Price, M. E., Brown, S., Dukes, A., \& Kang, J. (2015). Bodily attractiveness and egalitarianism are negatively related in males. Evolutionary Psychology, 13(1), 140-166. 
Price, M. E., Kang, J., Dunn, J., \& Hopkins, S. (2011). Muscularity and attractiveness as predictors of human egalitarianism. Personality and Individual Differences, 50(5), 636-640.

Price, M. E., Sheehy-Skeffington, J., Sidnaius, J., \& Pound, N. (2017). Is sociopolitical egalitarianism related to bodily and facial formidability in men? Evolution and Human Behavior, $38(5), 626-634$.

Priem, R. L., Lyon, D. W., \& Dess, G. G. (1999). Inherent limitations of demographic proxies in top management team heterogeneity research. Journal of Management, 25(6), 935-953.

Raub, S. (2017). When employees walk the company talk: The importance of employee involvement in corporate philanthropy. Human Resource Management, 56(5), 837-850.

Ravina, E. (2012). Love \& loans: The effect of beauty and personal characteristics in credit $\begin{array}{lllll}\text { markets. } & \text { SSRN. } & \text { Retrieved } & \text { September } & \text { 16, }\end{array}$ https://papers.ssrn.com/sol3/papers.cfm?abstract_id=1107307

Rule, N. O., \& Tskhay, K. O. (2014). The influence of economic context on the relationship between chief executive officer facial appearance and company profits. The Leadership Quarterly, 25(5), 846-854.

Sanchez-Pages, S., \& Turiegano, E. (2010). Testosterone, facial symmetry and cooperation in the prisoners' dilemma. Physiology \& Behavior, 99(3), 355-361.

Schmid, K., Marx, D., \& Samal, A. (2008). Computation of a face attractiveness index based on neoclassical canons, symmetry, and golden ratios. Pattern Recognition, 41(8), 2710-2717.

Seifert, B., Morris, S. A., \& Bartkus, B. R. (2003). Comparing big givers and small givers: Financial correlates of corporate philanthropy. Journal of Business Ethics, 45(3), 195-211. 
Shen, W., \& Cannella Jr, A. A. (2002). Power dynamics within top management and their impacts on CEO dismissal followed by inside succession. Academy of Management Journal, 45(6), $1195-$ 1206.

Shieh, G. (2010). On the misconception of multicollinearity in detection of moderating effects: Multicollinearity is not always detrimental. Multivariate Behavioral Research, 45(3), 483-507. Shinada, M., \& Yamagishi, T. (2014). Physical attractiveness and cooperation in a prisoner's dilemma game. Evolution and Human Behavior, 35(6), 451-455.

Siegel, P. A., \& Hambrick, D. C. (2005). Pay disparities within top management groups: Evidence of harmful effects on performance of high-technology firms. Organization Science, 16(3), 259274.

Singla, C., Veliyath, R., \& George, R. (2014). Family firms and internationalization-governance relationships: Evidence of secondary agency issues. Strategic Management Journal, 35(4), 606616.

Soleimanof, S., Rutherford, M. W., \& Webb, J. W. (2018). The intersection of family firms and institutional contexts: A review and agenda for future research. Family Business Review, 31(1), $32-53$.

Suchman, M. C. (1995). Managing legitimacy: Strategic and institutional approaches. Academy of Management Review, 20(3), 571-610.

Takahashi, C., Yamagishi, T., Tanida, S., Kiyonari, T., \& Kanazawa, S. (2006). Attractiveness and cooperation in social exchange. Evolutionary Psychology, 4(1), 315-329.

The million dollar donors report: India-2015 Report. (2015). Coutts.com. [Cited 17 January, 2019]. Available from URL: http://philanthropy.coutts.com/en/reports/2015/india/discussion.html 
Thompson, D. W., Panwar, R., \& Hansen, E. N. (2010). Examining social responsibility orientation gaps between society and industry executives. Management Decision, 48(1), 156-171. Torres-Reyna, O. (2007). Panel data analysis fixed and random effects using Stata (v. 4.2). Data \& Statistical Services, Priceton University.

Trichas, S., Schyns, B., Lord, R., \& Hall, R. (2017). "Facing” leaders: Facial expression and leadership perception. The Leadership Quarterly, 28(2), 317-333.

Tsujimura, H., \& Banissy, M. J. (2013). Human face structure correlates with professional baseball performance: Insights from professional Japanese baseball players. Biology Letters, 9(3), 1-4.

Vallejo, M. C. (2009). Analytical model of leadership in family firms under transformational theoretical approach: An exploratory study. Family Business Review, 22(2), 136-150.

Villalonga, B., \& Amit, R. (2006). How do family ownership, control and management affect firm value? Journal of Financial Economics, 80(2), 385-417.

Wasserman, N. (2006). Stewards, agents, and the founder discount: Executive compensation in new ventures. Academy of Management Journal, 49(5), 960-976.

Welker, K. M., Goetz, S. M., \& Carré, J. M. (2015). Perceived and experimentally manipulated status moderates the relationship between facial structure and risk-taking. Evolution and Human Behavior, 36(6), 423-429.

Westhead, P., \& Howorth, C. (2006). Ownership and management issues associated with family firm performance and company objectives. Family Business Review, 19(4), 301-316.

Zaatari, D., \& Trivers, R. (2007). Fluctuating asymmetry and behavior in the ultimatum game in Jamaica. Evolution and Human Behavior, 28(4), 223-227.

Zhao, K., Ferguson, E., \& Smillie, L. D. (2016). Prosocial personality traits differentially predict egalitarianism, generosity, and reciprocity in economic games. Frontiers in Psychology, 7, 1137. 
Zheng, Q., Luo, Y., \& Maksimov, V. (2015). Achieving legitimacy through corporate social responsibility: The case of emerging economy firms. Journal of World Business, 50(3), 389-403. 
Table 1: Descriptive Statistics and Correlation Matrix of Complete Sample $(n=1941)$

\begin{tabular}{|c|c|c|c|c|c|c|c|c|c|c|c|c|c|c|c|c|c|c|c|c|}
\hline & & 1 & 2 & 3 & 4 & 5 & 6 & 7 & 8 & 9 & 10 & 11 & 12 & 13 & 14 & 15 & 16 & 17 & 18 & 19 \\
\hline 1 & $\begin{array}{l}\text { LnCorporate } \\
\text { Philanthropy }\end{array}$ & 1 & & & & & & & & & & & & & & & & & & \\
\hline 2 & $\begin{array}{c}\text { Facial } \\
\text { Attractiveness } \\
\text { Index }\end{array}$ & -0.31 & 1 & & & & & & & & & & & & & & & & & \\
\hline 3 & FOC & 0.27 & 0.09 & 1 & & & & & & & & & & & & & & & & \\
\hline 4 & CEO Type & 0.21 & 0.12 & 0.23 & 1 & & & & & & & & & & & & & & & \\
\hline 5 & LnFirm Age & 0.2 & 0.1 & 0.08 & 0.11 & 1 & & & & & & & & & & & & & & \\
\hline 6 & LnFirm Size & 0.25 & 0.12 & 0.12 & 0.15 & 0.14 & 1 & & & & & & & & & & & & & \\
\hline 7 & $\begin{array}{l}\text { Cash-in-hand } \\
\text { (Slack) }\end{array}$ & 0.24 & 0.14 & 0.07 & 0.06 & 0.08 & 0.18 & 1 & & & & & & & & & & & & \\
\hline 8 & Bald Head & 0.002 & 0.008 & 0.003 & 0.002 & 0.001 & 0.004 & 0.003 & 1 & & & & & & & & & & & \\
\hline 9 & Eyeglasses & 0.008 & 0.005 & 0.009 & 0.005 & 0.004 & 0.002 & 0 & 0.004 & 1 & & & & & & & & & & \\
\hline 10 & Smiling Face & 0.004 & 0.001 & 0.004 & 0.008 & 0.002 & 0 & 0.003 & 0.009 & 0.001 & 1 & & & & & & & & & \\
\hline 11 & $\begin{array}{c}\text { Colored } \\
\text { Photograph }\end{array}$ & 0.005 & 0.007 & 0.003 & 0.007 & 0.009 & 0 & 0.005 & 0 & 0.005 & 0.004 & 1 & & & & & & & & \\
\hline 12 & CEO-MBA & 0.11 & 0.09 & 0.05 & 0.12 & 0.06 & 0.08 & 0.18 & 0.002 & 0.007 & 0 & 0.003 & 1 & & & & & & & \\
\hline 13 & $\begin{array}{l}\text { LnCEO- } \\
\text { Tenure }\end{array}$ & 0.11 & 0.14 & 0.08 & 0.16 & 0.17 & 0.14 & 0.14 & 0.003 & 0.0004 & 0.002 & 0.009 & 0.11 & 1 & & & & & & \\
\hline 14 & CEO-fWHR & -0.15 & 0.001 & 0.1 & 0.08 & 0.05 & 0.002 & 0.09 & 0.007 & 0.004 & 0.0003 & 0.0002 & 0.06 & 0.09 & 1 & & & & & \\
\hline 15 & ROA & 0.05 & 0.06 & 0.1 & 0.07 & 0.02 & 0.01 & 0.03 & 0 & 0.0001 & 0.0005 & 0.0003 & 0.01 & 0.04 & 0.06 & 1 & & & & \\
\hline 16 & Skin Color & 0.135 & 0.163 & 0.009 & 0.007 & 0 & 0.005 & 0.001 & 0.003 & 0.002 & 0.006 & 0.0002 & 0.0008 & 0.0003 & 0.0001 & 0.0002 & 1 & & & \\
\hline 17 & $\begin{array}{l}\text { CEO Vertical } \\
\text { Pay Gap }\end{array}$ & $\overline{-}-\overline{215}$ & 0.123 & $\overline{-}$ & $\begin{array}{c}- \\
0.098\end{array}$ & 0.105 & 0.096 & 0.117 & 0.005 & 0.006 & 0.001 & 0.0003 & 0.108 & 0.085 & 0.084 & 0.073 & 0.105 & 1 & & \\
\hline 18 & $\begin{array}{l}\text { Horizontal } \\
\text { Pay Gap }\end{array}$ & $-\overline{-}$ & 0.116 & $\begin{array}{c}- \\
0.105\end{array}$ & $-\overline{-}$ & $\begin{array}{c}- \\
0.097\end{array}$ & 0.072 & 0.11 & 0.003 & 0.004 & 0.002 & 0.0006 & 0.082 & 0.063 & 0.075 & 0.068 & 0.082 & 0.113 & 1 & \\
\hline \multirow[t]{3}{*}{19} & LnRevenue & 0.356 & 0.109 & 0.078 & 0.065 & 0.134 & 0.113 & 0.144 & 0.007 & 0.001 & 0.005 & 0 & 0.07 & 0.058 & 0.034 & 0.113 & 0.031 & 0.108 & 0.104 & 1 \\
\hline & Mean & 1.28 & 7.2 & 0.48 & 0.44 & 4.6 & 5.1 & 8.3 & 0.13 & 0.27 & 0.67 & 0.92 & 0.26 & 2.7 & 1.74 & 3.5 & 3.1 & 2.83 & 0.36 & 7.47 \\
\hline & S.D. & 1.01 & 1.24 & 0.42 & 0.96 & 1.52 & 2.34 & 9.7 & 0.45 & 0.53 & 0.49 & 0.31 & 0.431 & 1.1 & 0.48 & 9.8 & 1.3 & 2.01 & 0.34 & 3.32 \\
\hline
\end{tabular}


Table 2: Results of Regression Analysis and Mediation Analysis ( $n=1941)$

\begin{tabular}{|c|c|c|c|c|c|c|c|c|c|c|c|c|}
\hline \multirow{2}{*}{ Variable } & \multicolumn{3}{|c|}{$\begin{array}{c}\text { Model 0 } \\
\text { LnCorporate Philanthropy } \\
\end{array}$} & \multicolumn{3}{|c|}{ LnCorporate Philanthropy } & \multicolumn{3}{|c|}{$\begin{array}{c}\text { Mediation Models } \\
\text { CEO Pay Gap (Vertical) } \\
\end{array}$} & \multicolumn{3}{|c|}{ CEO Pay Gap (Horizontal) } \\
\hline & $\begin{array}{c}\beta \\
(1)\end{array}$ & s.e. & p. value & $\begin{array}{c}\beta \\
(4)\end{array}$ & s.e. & p. value & $\begin{array}{c}\beta \\
(7)\end{array}$ & s.e. & p. value & $\begin{array}{c}\beta \\
(\mathbf{1 0})\end{array}$ & s.e. & p. value \\
\hline Facial Attractiveness Index & -0.056 & 0.02 & 0.005 & -0.06 & 0.02 & 0.001 & 0.273 & 0.09 & 0.003 & 0.125 & 0.04 & 0.000 \\
\hline CEO Pay Gap (Vertical) & & & & -0.127 & 0.04 & 0.000 & & & & & & \\
\hline CEO Pay Gap (Horizontal) & & & & -0.116 & 0.04 & 0.002 & & & & & & \\
\hline Firm Age & 0.21 & 0.15 & 0.161 & 0.23 & 0.17 & 0.177 & 0.182 & 0.11 & 0.083 & 0.131 & 0.1 & 0.17 \\
\hline Firm Size & 0.173 & 0.109 & 0.112 & 0.168 & 0.1 & 0.078 & 0.126 & 0.08 & 0.115 & 0.108 & 0.067 & 0.107 \\
\hline Cash-in-hand (Slack) & 0.181 & 0.06 & 0.001 & 0.175 & 0.05 & 0.000 & -0.132 & 0.07 & 0.049 & -0.112 & 0.086 & 0.193 \\
\hline Bald Head & -0.01 & 0.01 & 0.317 & -0.01 & 0.01 & 0.23 & -0.007 & 0.006 & 0.246 & 0.005 & 0 & 0.097 \\
\hline Eyeglasses & 0.09 & 0.13 & 0.49 & 0.07 & 0.11 & 0.63 & 0.015 & 0.03 & 0.66 & 0.011 & 0.02 & 0.638 \\
\hline Smiling Face & 0.005 & 0.01 & 0.617 & 0.004 & 0.01 & 0.66 & 0.017 & 0.09 & 0.857 & 0.011 & 0.03 & 0.713 \\
\hline Colored Photograph & 0.002 & 0.01 & 0.841 & 0.003 & 0.01 & 0.5 & 0.009 & 0.04 & 0.822 & 0.001 & 0.005 & 0.841 \\
\hline Skin color & 0.032 & 0.02 & 0.109 & 0.036 & 0.03 & 0.15 & 0.021 & 0.02 & 0.271 & 0.035 & 0.02 & 0.144 \\
\hline CEO-MBA & 0.073 & 0.06 & 0.234 & 0.078 & 0.06 & 0.22 & 0.084 & 0.07 & 0.243 & 0.047 & 0.065 & 0.469 \\
\hline LnCEO Tenure & 0.11 & 0.09 & 0.221 & 0.13 & 0.1 & 0.194 & 0.175 & 0.13 & 0.193 & 0.223 & 0.157 & 0.155 \\
\hline CEO-fWHR & -0.09 & 0.06 & 0.133 & -0.09 & 0.06 & 0.17 & -0.036 & 0.025 & 0.15 & -0.018 & 0.016 & 0.262 \\
\hline ROA & 0.073 & 0.05 & 0.144 & 0.078 & 0.05 & 0.12 & 0.055 & 0.036 & 0.012 & 0.021 & 0.015 & 0.161 \\
\hline LnRevenue & 0.218 & 0.07 & 0.000 & 0.216 & 0.06 & 0.000 & 0.042 & 0.01 & 0.002 & 0.022 & 0.007 & 0.001 \\
\hline Adjusted $\mathbf{R}^{2}$ & & 0.186 & & & 0.248 & & & 0.234 & & & 0.226 & \\
\hline
\end{tabular}


Table 3: CEO and Horizontal Pay Gap Mediation Models (Indirect Effect)

CEO Vertical Pay Gap Mediation Model

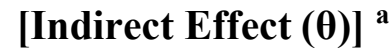

(1)
CEO Horizontal Pay Gap Mediation Model [Indirect Effect $(\theta)]^{\text {a }}$

(2)

$-0.0485(-0.0520 /-0.0389)$ $-0.0361(-0.0392 /-0.0297)$

${ }^{a}$ The indirect effect, indicates statistical significance at $95 \%$ confidence interval. The lower confidence interval (LCI) statistic is before the slash and the upper confidence interval (UCI) statistic is after the slash in the bracket. 
Table 4a Results of Moderated-Mediation Regressions (Moderator is FOC) $(n=1941)$

\begin{tabular}{|c|c|c|c|c|c|c|c|c|c|}
\hline \multirow[b]{2}{*}{ Variable } & \multicolumn{3}{|c|}{ LnCorporate Philanthropy } & \multicolumn{3}{|c|}{ CEO Pay Gap (Vertical) } & \multicolumn{3}{|c|}{ CEO Pay Gap (Horizontal) } \\
\hline & $\begin{array}{c}\boldsymbol{\beta} \\
(\mathbf{1})\end{array}$ & s.e. & p. value & $\begin{array}{c}\beta \\
(4) \\
\end{array}$ & s.e. & p. value & $\begin{array}{c}\boldsymbol{\beta} \\
(7) \\
\end{array}$ & s.e. & p. value \\
\hline CEO Pay Gap (Vertical) & -0.124 & 0.04 & 0.001 & & & & & & \\
\hline CEO Pay Gap (Horizontal) & -0.11 & 0.035 & 0.001 & & & & & & \\
\hline CEO Pay Gap (Horizontal)*FOC & 0.049 & 0.015 & 0.001 & & & & & & \\
\hline FOC & 0.046 & 0.016 & 0.004 & & & & & & \\
\hline Firm Age & 0.18 & 0.12 & 0.133 & 0.182 & 0.105 & 0.083 & 0.131 & 0.095 & 0.17 \\
\hline Firm Size & 0.161 & 0.095 & 0.091 & 0.126 & 0.08 & 0.115 & 0.108 & 0.067 & 0.107 \\
\hline Cash-in-hand (Slack) & 0.164 & 0.049 & 0.000 & -0.132 & 0.067 & 0.049 & -0.112 & 0.086 & 0.193 \\
\hline Bald Head & -0.001 & 0.0008 & 0.211 & -0.007 & 0.006 & 0.246 & 0.005 & 0.003 & 0.097 \\
\hline Smiling Face & 0.002 & 0.005 & 0.689 & 0.017 & 0.09 & 0.857 & 0.011 & 0.03 & 0.713 \\
\hline Colored Photograph & 0.007 & 0.006 & 0.246 & 0.009 & 0.04 & 0.822 & 0.001 & 0.005 & 0.841 \\
\hline Skin color & 0.027 & 0.018 & 0.133 & 0.021 & 0.019 & 0.271 & 0.035 & 0.024 & 0.144 \\
\hline СЕО-МВА & 0.071 & 0.056 & 0.207 & 0.084 & 0.072 & 0.243 & 0.047 & 0.065 & 0.469 \\
\hline LnCEO Tenure & 0.11 & 0.07 & 0.116 & 0.175 & 0.134 & 0.193 & 0.223 & 0.157 & 0.155 \\
\hline CEO-fWHR & -0.075 & 0.054 & 0.167 & -0.036 & 0.025 & 0.15 & -0.018 & 0.016 & 0.262 \\
\hline ROA & 0.071 & 0.049 & 0.15 & 0.055 & 0.036 & 0.128 & 0.021 & 0.015 & 0.161 \\
\hline LnRevenue & 0.202 & 0.061 & 0.000 & 0.042 & 0.014 & 0.002 & 0.022 & 0.007 & 0.001 \\
\hline Adjusted $\mathbf{R}^{2}$ & & 0.253 & & & 0.242 & & & 0.231 & \\
\hline
\end{tabular}


Table 4b Results of Moderated-Mediation Regressions (Moderator is CEO Type) (n=1941)

\begin{tabular}{|c|c|c|c|c|c|c|c|c|c|}
\hline \multirow[b]{2}{*}{ Variable } & \multicolumn{3}{|c|}{ LnCorporate Philanthropy } & \multicolumn{3}{|c|}{ CEO Pay Gap (Vertical) } & \multicolumn{3}{|c|}{ CEO Pay Gap (Horizontal) } \\
\hline & $\begin{array}{c}\boldsymbol{\beta} \\
(\mathbf{1})\end{array}$ & s.e. & p. value & $\begin{array}{c}\boldsymbol{\beta} \\
(4)\end{array}$ & s.e. & p. value & $\begin{array}{c}\boldsymbol{\beta} \\
(7)\end{array}$ & s.e. & p. value \\
\hline Facial Attractiveness Index & 0.051 & 0.017 & 0.002 & 0.273 & 0.092 & 0.003 & 0.125 & 0.036 & 0.000 \\
\hline CEO Pay Gap (Vertical) & -0.171 & 0.052 & 0.001 & & & & & & \\
\hline CEO Pay Gap (Horizontal) & -0.108 & 0.035 & 0.002 & & & & & & \\
\hline $\begin{array}{c}\text { CEO Pay Gap (Vertical)* CEO } \\
\text { Type }\end{array}$ & 0.052 & 0.015 & 0.000 & & & & & & \\
\hline $\begin{array}{c}\text { CEO Pay Gap (Horizontal)*CEO } \\
\text { Type }\end{array}$ & 0.043 & 0.013 & 0.000 & & & & & & \\
\hline CEO type & 0.032 & 0.011 & 0.003 & & & & & & \\
\hline Firm Age & 0.21 & 0.15 & 0.161 & 0.182 & 0.105 & 0.083 & 0.131 & 0.095 & 0.17 \\
\hline Firm Size & 0.151 & 0.087 & 0.083 & 0.126 & 0.08 & 0.115 & 0.108 & 0.067 & 0.107 \\
\hline Cash-in-hand (Slack) & 0.169 & 0.048 & 0.000 & -0.132 & 0.067 & 0.049 & -0.112 & 0.086 & 0.193 \\
\hline Bald Head & -0.005 & 0.004 & 0.211 & -0.007 & 0.006 & 0.246 & 0.005 & 0.003 & 0.097 \\
\hline Eyeglasses & 0.056 & 0.114 & 0.624 & 0.015 & 0.034 & 0.66 & 0.011 & 0.023 & 0.632 \\
\hline Smiling Face & 0.003 & 0.008 & 0.707 & 0.017 & 0.09 & 0.857 & 0.011 & 0.03 & 0.713 \\
\hline Colored Photograph & 0.001 & 0.005 & 0.841 & 0.009 & 0.04 & 0.822 & 0.001 & 0.005 & 0.841 \\
\hline Skin color & 0.031 & 0.022 & 0.158 & 0.021 & 0.019 & 0.271 & 0.035 & 0.024 & 0.144 \\
\hline СЕО-MBA & 0.081 & 0.072 & 0.262 & 0.084 & 0.072 & 0.243 & 0.047 & 0.065 & 0.469 \\
\hline LnCEO Tenure & 0.145 & 0.121 & 0.234 & 0.175 & 0.134 & 0.193 & 0.223 & 0.157 & 0.155 \\
\hline CEO-fWHR & -0.089 & 0.065 & 0.171 & -0.036 & 0.025 & 0.15 & -0.018 & 0.016 & 0.262 \\
\hline ROA & 0.067 & 0.047 & 0.155 & 0.055 & 0.036 & 0.128 & 0.021 & 0.015 & 0.161 \\
\hline LnRevenue & 0.22 & 0.067 & 0.001 & 0.042 & 0.014 & 0.002 & 0.022 & 0.007 & 0.001 \\
\hline Adjusted $\mathbf{R}^{2}$ & & 0.250 & & & 0.247 & & & 0.238 & \\
\hline
\end{tabular}


Table 5a: Indirect Effects at Different Levels of Moderators (Mediator: CEO Pay Gap (Vertical) as mediator)

\begin{tabular}{|c|c|c|c|}
\hline \multicolumn{2}{|c|}{$\begin{array}{c}\text { Moderated-Mediation Model for CEO } \\
\text { Pay Gap (Vertical) as mediator and } \\
\text { FOC as moderator }\end{array}$} & \multicolumn{2}{|c|}{$\begin{array}{l}\text { Moderated-Mediation Model for CEO Pay } \\
\text { Gap (Vertical) as mediator and CEO Type } \\
\text { as moderator }\end{array}$} \\
\hline & (1) & & (2) \\
\hline $\begin{array}{l}\text { Family Ownership } \\
\text { Concentration b }\end{array}$ & $\begin{array}{l}\text { [Indirect Effect } \\
(\theta)]^{\mathrm{a}}\end{array}$ & CEO Type & {$[\text { Indirect } \operatorname{Effect}(\theta)]^{a}$} \\
\hline Low (0.06) & $\begin{array}{c}-0.0325(-0.0362 /- \\
0.0288)\end{array}$ & $\begin{array}{l}\text { Non-Family } \\
\text { CEO }\end{array}$ & $-0.0338(-0.0371 /-0.0263)$ \\
\hline Medium (0.48) & $\begin{array}{c}-0.0258(-0.0279 /- \\
0.0228)\end{array}$ & \multirow{2}{*}{ Family CEO } & \multirow{2}{*}{$-0.0196(-0.0210 /-0.0149)$} \\
\hline High (0.90) & $\begin{array}{c}-0.0188(-0.0225 /- \\
0.0137)\end{array}$ & & \\
\hline
\end{tabular}

${ }^{a}$ The indirect effect, indicates statistical significance at $95 \%$ confidence interval. The lower confidence interval (LCI) statistic is before the slash and the upper confidence interval (UCI) statistic is after the slash in the bracket.

${ }^{b}$ Mean denotes the mean value, low denotes one s.d. below the mean value; high denotes one s.d. above the mean value. 
Table 5b: Indirect Effects at Different Levels of Moderators (Mediator: CEO Pay Gap (Horizontal) as mediator)

\begin{tabular}{|c|c|c|c|}
\hline \multicolumn{2}{|c|}{$\begin{array}{l}\text { Moderated-Mediation Model for CEO } \\
\text { Pay Gap (Horizontal) as mediator and } \\
\text { FOC as moderator }\end{array}$} & \multicolumn{2}{|c|}{$\begin{array}{c}\text { Moderated-Mediation Model for CEO Pay } \\
\text { Gap (Horizontal) as mediator and CEO } \\
\text { Type as moderator }\end{array}$} \\
\hline & (1) & & (2) \\
\hline $\begin{array}{c}\text { Family Ownership } \\
\text { Concentration b }\end{array}$ & $\begin{array}{l}\text { [Indirect Effect } \\
(\theta)]^{\mathrm{a}}\end{array}$ & CEO Type & {$[\text { Indirect Effect }(\theta)]^{a}$} \\
\hline Low (0.06) & $\begin{array}{c}-0.0292(-0.0318 /- \\
0.0264)\end{array}$ & $\begin{array}{l}\text { Non-Family } \\
\text { CEO }\end{array}$ & $-0.0300(-0.0326 /-0.0255)$ \\
\hline Medium (0.48) & $\begin{array}{c}-0.0236(-0.0256 /- \\
0.0221)\end{array}$ & \multirow{2}{*}{ Family CEO } & \multirow{2}{*}{$-0.0182(-0.0207 /-0.0146)$} \\
\hline High (0.90) & $\begin{array}{c}-0.0179(-0.0211 /- \\
0.0138\end{array}$ & & \\
\hline
\end{tabular}

${ }^{a}$ The indirect effect, indicates statistical significance at 95\% confidence interval. The lower confidence interval (LCI) statistic is before the slash and the upper confidence interval (UCI) statistic is after the slash in the bracket.

${ }^{\mathrm{b}}$ Mean denotes the mean value, low denotes one s.d. below the mean value; high denotes one s.d. above the mean value. 
Figure 1: Image Appearance Over Anaface.com with Markers

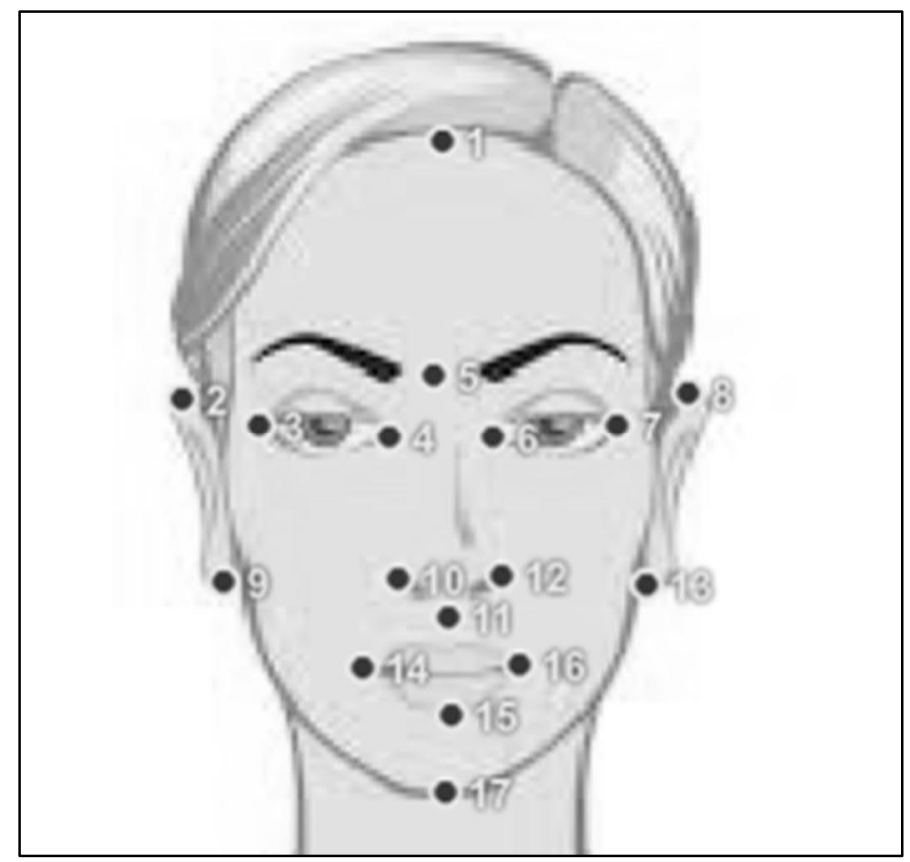


Figure 2: Conceptual models of the Study

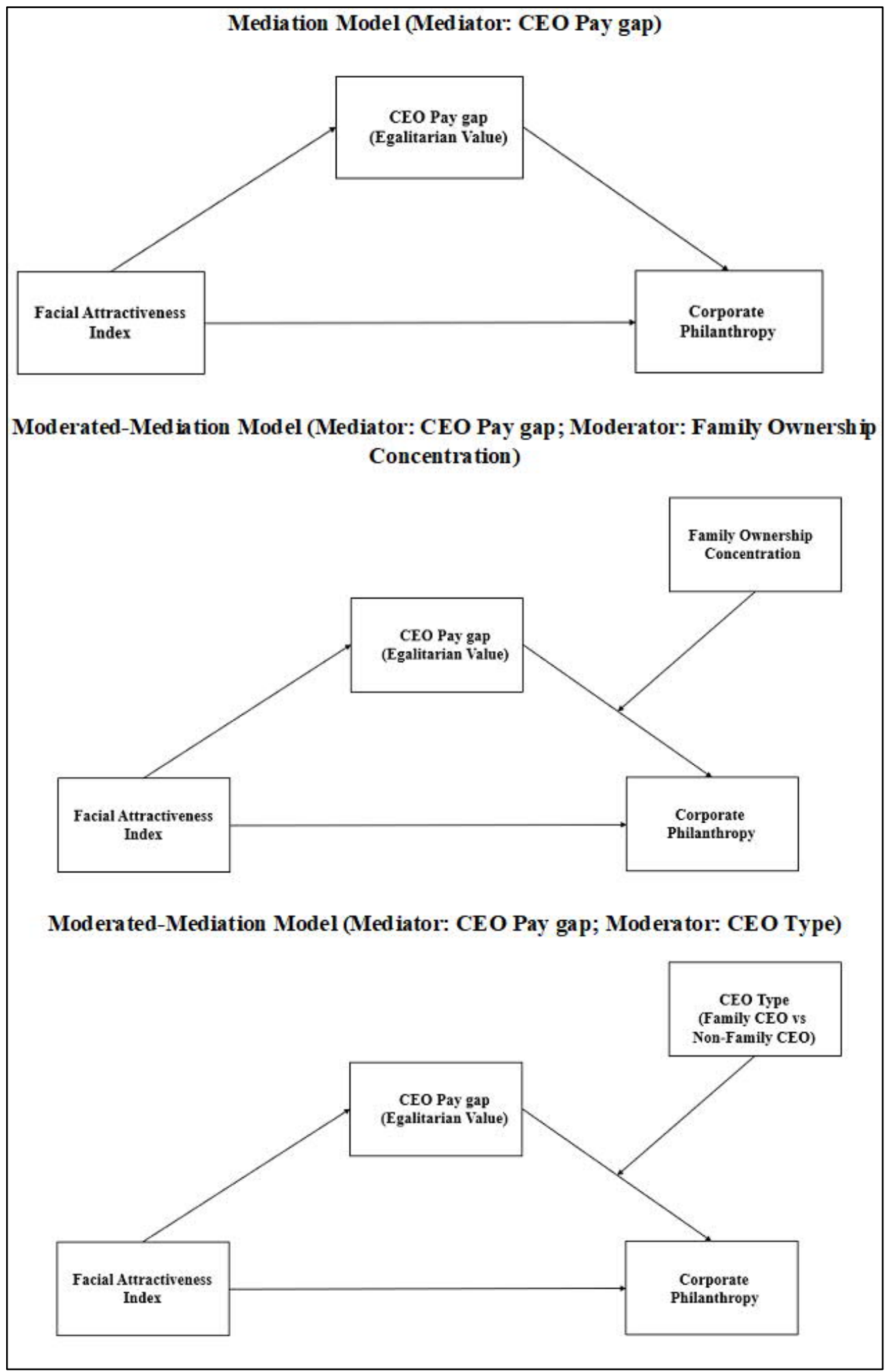

